\title{
Modeling Political Belief and Its Propagation, with Malaysia as a Driving Context
}

\author{
Nordin Zakaria \\ High-Performance Computing Center, Universiti Teknologi PETRONAS, Perak, Malaysia \\ Email: nordinzakaria@petronas.com.my
}

Received 7 January 2014; revised 12 February 2014; accepted 4 March 2014

Copyright (C) 2014 by author and Scientific Research Publishing Inc.

This work is licensed under the Creative Commons Attribution International License (CC BY). http://creativecommons.org/licenses/by/4.0/

c) (i) Open Access

\begin{abstract}
We discuss in this paper an agent-based social simulation model that describes the propagation of political belief in Malaysia. Worldview map is used as the representational scheme for political belief. Inter-agent interaction propagates the belief throughout the agent population, subject to similarity of emotion between the interacting agents and their distances apart, and various attributes of the individual agents. Media broadcast may be used by agents in their attempt to extend their reach. Computational experiments made using the model point to its plausibility. Further, it highlights, for the ruling coalition, the importance of both a strong political propaganda machinery and a strong governance in winning the hearts and minds of the electorate.
\end{abstract}

\section{Keywords}

\section{Agent-Based Simulation, Social Simulation, Political Belief, Malaysia}

\section{Introduction}

While social simulation has in recent years been maturing as a discipline on its own, there has been relatively few works that discuss its development in the context of specific political situations especially that in the developing and under-developed countries. Such work would be beneficial in providing insight on how the politics in such countries can be better understood and administered, a benefit especially important considering the correlation between political stability and progress (Aisen \& Veiga, 2011). Further, it would serve to showcase the usefulness of social simulation in the context of real-world politics and the growth of nations. Towards this end, in this paper, we focus on Malaysia and develop a social simulation to study Malaysian political development in recent time, especially on the intense period of time leading to the thirteenth Malaysian general election (GE13), and up to a few months after its conclusion.

The GE13 saw the incumbent government in Malaysia retaining its rule by winning around $60 \%$ of the seats, 
yet failing to capture the economically important states of Selangor and Penang, and winning only $47.3 \%$ of the popular vote. The election, in a country of 28 million people, where the Bumiputera (ethnic Malays and other indigenous groups) forms 60.3 percent of the population, Chinese 22.9 percent, Indians 7.1 percent, and various other immigrant groups making up the rest, saw a massive swing of Chinese and urban votes against the government.

The ruling coalition, the Barisan Nasional (BN), comprised of the dominant United Malays Nationalist Organisation (UMNO), the Malaysian Chinese Association (MCA), the Malaysian Indian Congress (MIC), and several smaller parties. The opposition, the People's Alliance (Pakatan Rakyat), led by former Deputy Prime Minister Anwar Ibrahim, composed of the People's Justice Party (Parti Keadilan Rakyat, PKR), the Democratic Action Party (DAP) and the Pan-Malaysian Islamic Party (Parti Islam Se-Malaysia, PAS).

The result was surprising (and disappointing) for many government supporters as the Prime Minister, Najib Razak, was seen to have spent many months carefully planning and spending for the election in an effort to reverse the trend seen in the twelfth general election, where the government lost for the first time since 1969, its two-third parliamentary majority.

Adding further to the surprise was the fact that Najib Razak was seen by many to have actively pursued reforms, and these included repealing, replacing or amending liberty-inhibiting laws such as the Internal Security Act (ISA), taking steps towards improving minority education ${ }^{1}$ and educational opportunities ${ }^{2}$, and pursuing national integration through his 1Malaysia vision (Salleh, 2010).

So what went wrong (for the ruling party)? Blames have been placed on the Internet, pro-BN figures pointing to its polarizing effect, and pro-PR counterparts lauding its ability to open up democratic opportunities (see, for example, Subramaniam, 2011). Observers, and Najib himself ${ }^{3}$, noted that in spite of all that BN had actually done and was doing for the nation, it had actually lost the propaganda war, especially in cyber space and especially where the Chinese and urban community were concerned. Some pointed that regardless of the Internet, BN agents were simply hopeless against PR's far more charismatic, resourceful and committed figures ${ }^{4}$. In fact, especially in cyberspace, BN was an underdog, outnumbered and outflanked by the thousands of opposition cybertroopers bent on breaking BN's domination. Adding further to the problem (for BN), was the numerous factors, that the people, especially the middle-class, had to grapple with then, and these included especially inflation, rising crime rate and fluctuating educational quality.

While the result was rationalized by some as a "fair" and "balanced" reflection of Malaysian's political reali$t^{5}$, especially worrying for responsible policy makers and community leaders was the divisiveness of politics that led up to the election. Politics at times reached down to the gutter ${ }^{6}$, marked by personal attacks and smearing, virile videos, malicious online posting, and blatantly one-sided news articles. And polarization, a sinkhole for a multiracial society such as Malaysia, ensued when electorates en mass could not differentiate fallacies from sound arguments, facts from half-facts, and took side fanatically based more on emotional perception planted in by politicians rather than sound reasoning. As put by Calvin Sankaran, "...they will only see and hear what they want to see and hear-irrespective of the persuasiveness of argument and the strengths of facts to the contrary. To these people, truth is defined as news reports and facts that confirms and reinforces the pre-existing perception that has been deeply ingrained into their consciousness. Anything that doesn't is automatically rejected as propaganda and lies." Hence, while politics has been further democratized or liberalized in Malaysia en route to GE13, some aspects of it have been certainly less than healthy.

Given the motivating factor being to understand the complexity of Malaysian politics within the stated time period, we state the research question being addressed in this exploratory paper as follows: Can the dynamics of Malaysian politics be captured in social simulation? Can we infer useful insight from the simulation? To address the question, we focus on the perception war in the run up to GE13. While there have been plenty of largely qu-

\footnotetext{
${ }^{1}$ See for example "PM Announces RM30mil Grant for Chinese Schools”, The Star, 21 October 2012.

${ }^{2}$ See for example "PM: Full Scholarship for Top 100 Indian Undergrads”, New Straits Times, 18 March 2012.

${ }^{3}$ Najib was quoted as saying: "If there is any weakness in the Government, it could be that we are not so good in dealing with the war on perception,” 3 June 2013, The Star.

${ }^{4}$ See for example: "Kit Siang gets rock star treatment in NS”, 29 April 2013, The Edge.

${ }^{5}$ See Marina Mahathir, “GE13; A Very Malaysian Result”, The Star, $13^{\text {th }}$ May 2013.

${ }^{6}$ See for example: see for example "It’s Gutter Politics, says Mahathir”, The Star, Feb 20, 2009. Also "Sex, sabotage and videotape in Malaysian campaign”, 21 April8 2013, Agence-France Presse.

${ }^{7}$ Calvin Sankaran, GE13; How BN lost the battle for perception, 16 May 2013, Malaysia Today,

http://www.malaysia-today.net/mtcolumns/letterssurat/56792-ge13-how-bn-lost-the-battle-of-perception
} 
alitative discussion on the subject, our hypothesis is that computer simulation would help to provide insights on the way and the factors that affect the way in which political belief spreads in Malaysian society.

\section{Related Work}

The work of Deffuant et al. (2002) bears some influence on this paper. In (Deffuant 2002), the authors modeled opinion dynamics in populations of agents with continuous opinion and uncertainty. The opinions and uncertainties were modified by random pair interactions. They proposed a model of interactions, called relative agreement model, where uncertainty as well as opinion could be modified by interactions. An extremist agent was characterized by a much lower uncertainty. In our work, noting the complexity of actual political opinions, we need to assume a more structured form for agent's opinion, one that embodies the notion of 'certainty' and resistance to change, and as will be discussed later, we further complement to it a 'stubbornness' attribute.

Other agent-based simulation work that focuses on opinion formation includes that of Mare and Latora (2007). They studied the dynamics of opinion formation within a game theoretic framework. The process of opinion formation was considered to be a decision making process. An agent could choose to maintain its opinion or to change in accordance with that of another agent. While the work is theoretically interesting, it is unclear as to how it would map onto the context of interest in this paper. In another work, Iniguez et al. (2011) studied the propagation of opinions in a social network. An agent's opinion is assumed to be a bounded scalar value, the value of which denotes the agent's inclination (positive or negative) with regard to a particular issue. Links may be formed and deleted dynamically throughout a simulation. Links between agents may be deleted with a probability proportional to the opinion difference between the agents. Within the problem context of this paper, the incorporation of social networking would indeed be natural especially if one were to consider social media as a political medium. However, we choose in this paper to consider only broadly the role played by the Internet, a term under which we lump all the different communication tools: social media, news portal, blogs, forums, etc. Muis (2010) sought to explore, through simulation, the role of the media in electoral politics, and to explain as to why newer political parties find it difficult to gain ground in a democratic election. While the simulation result was consistent with empirical electoral data from a time period in the Netherlands from 1998 to 2002, he assumed only traditional media, and did not consider the broadcasting capability of the Internet.

Along a different dimension, Kottonau and Wostl (2004) focused on the formation of political attitude strength. A stronger attitude denoted the greater the probability an agent would participate in an election. The change in position due to the communication assumed depended largely on the certainty and credibility of the agents involved, and was dictated by what they called the PASS (Political Attitude Strength Simulation) model. The role of emotion was not considered. In the context of this paper, we need to capture the role of emotion, and further, due to the high voluntary turnout (90\%) in GE13, and our own observation of a very high citizen participation, the issue of attitude strength and politically awareness (Zaller, 1992) plays a lesser role.

A different sort of agent-based simulation is in Silverman et al. (2006). They discussed a political strategy game that simulated ethno-political conflicts. The game involved agents that belonged to one or more groups based on norms, sacred values, languages and such, each group competing for dominance and resource control. We do not consider resource competition in this paper, though such emphasis might be very relevant when considering Malaysian politics in a broader context.

And as far as case studies are concerned, only a few works thus far can be classified as being under this category. Geller et al. (2011) focused on socioeconomic issues to explain how the Afghan drug industry was sustained by its political players. Gulden (2012) applied a game-theoretic framework to study the cycle of violence in the Guatemalan Civil War, and showed, through simulations, the relationship between ethnic composition and the level of political violence in a specific zone. The work as presented in this paper, being very specific to the Malaysian political experience, may be categorized as a case study. It is important to note that while a case study might not directly contribute to the fundamentals of agent-based simulation or to political science itself, it serves to demonstrate the applicability or feasibility of using simulation to study a real-world problem, illustrating its usefulness, and possibly guiding further fundamental research.

\section{Framework}

The essence of our approach is depicted in Figure 1. Agents interact with one another, and each has a number of features, pertinent among which are emotion, communication skill and influence, stubbornness, and opinions 


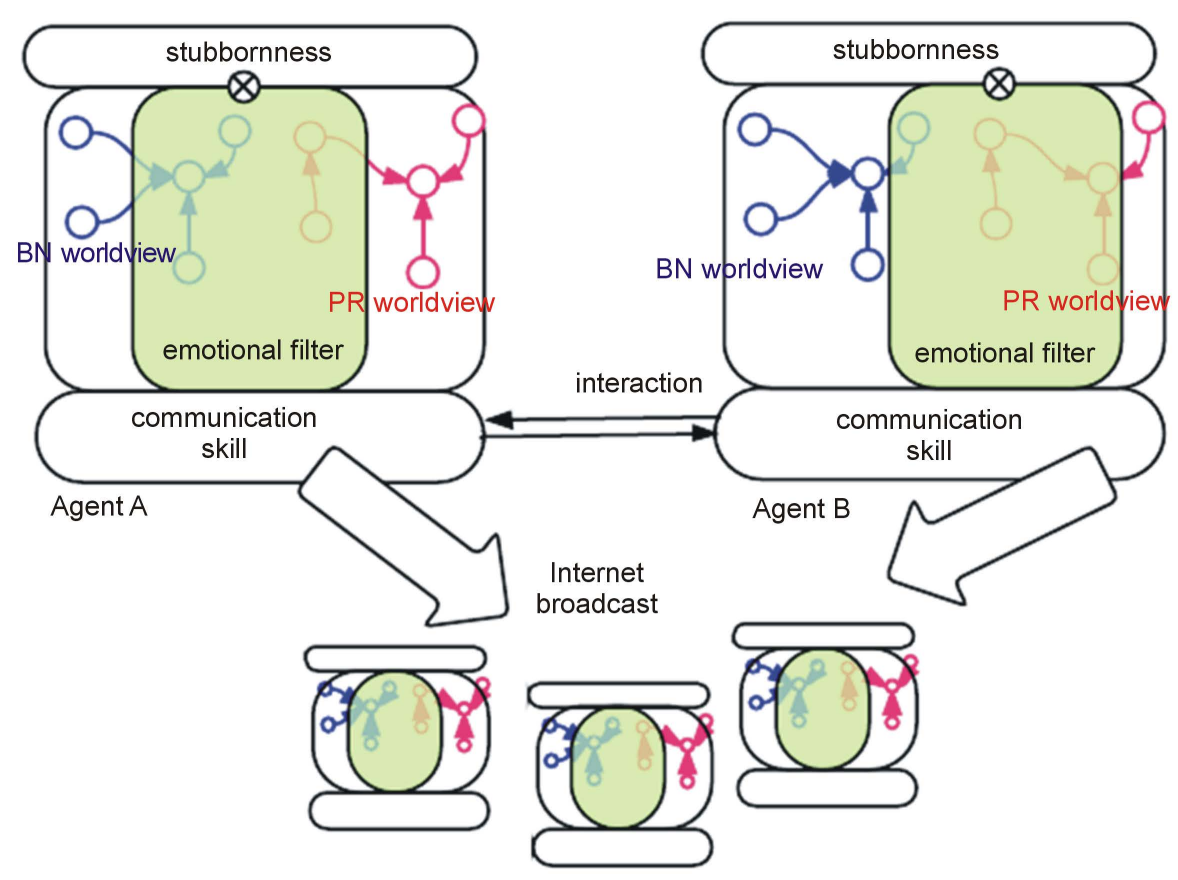

Figure 1. Proposed framework.

structured in the form of a worldview or mental map. Multiple opinions persist in an agent, an emotional filter determining the one which is salient. Agents interact in order to propagate its belief, locally and at times globally using Internet broadcast. More details will be exposed in the sections to follow.

\subsection{Worldview Map}

We model the worldview of individuals in a simulated society using graphical network notation. A worldview depicts a person's thought process about how something works in the real world. It represents the surrounding world, and the relationships between its various parts. In the context of this paper, it serves a purpose similar to the cultural network analysis (CNA) in Sieck $(2010,2011)$-it facilitates studying in detail the common perspective that members of a culture bring to a situation. The specific form of the worldview that we assume is that which we consider to be the most common in the Malaysian political context, and will be presented later.

We represent a worldview map as an $N$-node tree. Each node, $n_{i}$, in the map represents a notion or statement. Each edge, $\left\{n_{k}, n_{l}\right\}$, connecting between 2 nodes, $n_{k}$ and $n_{l}(0 \leq k<N$ and $0 \leq l<N)$, represents a link between two notions. It has a weight, $w^{k l}, 0 \leq w^{k l} \leq 1$, that represents the strength of the connection between the concepts. A stronger weight denotes a strong argument for the connection, while a weak weight denotes otherwise.

The overall weight of a map is obtained as the average over all the weights in the map, as follows: $w_{\text {total }}=\sum w^{k l} / W$ where $W$ is the total number of edges or weights in the map.

Political conflict ensues when different sides, having different worldview maps pertaining to an issue, communicate past one another. This means that two people can experience the same situation, but pay attention to entirely different things and take away different ideas about the causes and effects of an experience. In the context of Malaysian politics, it explains the continual dichotomy between opposing sections of society ${ }^{8}$.

A network notation has two main advantages. First, it allows us to map out the thought systems of the opposing parties, allowing us to objectively understand the position of each. Secondly, the network notation, in computing terms, translates to standard tree data structure, allowing for efficient computation and simulation, enabling understanding of the macroscopic behavior that emerges in society when ideas interact.

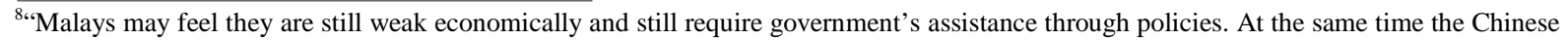
may have different considerations," said Najib. "So, one of our challenges is to manage this political dichotomy in our community," he added. The Malaysian Insider, August 20, 2010.
} 


\subsection{Worldviews Assumed}

\subsubsection{Disclaimer and Scope}

The author asserts that this paper is written with no intentional bias towards either the ruling party or the opposition in Malaysia. The goal is purely academic — to develop social simulation for the study of socio-political reality in the country and to infer insights into her political development.

The maps to be shown in the next sections were derived from various sources (mostly online) and the author's personal observation in months leading to GE13, and up to a few months upon its conclusion. The author made observations through his interactions with various individuals (including family members and colleagues) with different political orientations, participation in online forums and debates, and years of following the Malaysian political scenes. Hence, the maps are illustrative in purpose; its method of derivation a form of political ethnography, akin to the treatment in (Weiss, 2013). A more rigorous approach, one which would be needed for an "outsider" to understand a foreign society, would be something akin to Sieck's cultural map analysis, a method that incorporates eliciting of ideas from people in interviews, extraction of ideas from interview transcripts, analysis of common ideas and alignment and assembling of common ideas into complete maps.

\subsubsection{The PR Worldview}

The worldview map held by a "typical” PR supporter is, based on the author's observation, as depicted in Figure 2. The primary points in this worldview are that BN rules are marked by the following:

1) Poor governance

a) Crime; Crime—robbery, snatch theft—has been reaching an epidemic level, especially in the cities ${ }^{9}$. The police has been weak and ineffective, being unable to do anything much about this.

b) Middle-class trap; Government policies has caused large brain drain. And due to the brain drain, Malaysia is not likely to be able to escape the middle-income trap ${ }^{10}$.

c) Inflation; Food, petrol are still too expensive, especially for the struggling working class ${ }^{11}$.

d) Government departments, dominated by Malays, are under-performing; Government departments are bureaucratic and largely inefficient and corrupted ${ }^{12}$.

2) Corruption

a) Government has long engaged in money politics. B1RM (cash payment from the government to the low-income) and other government handouts are embodiment of money for votes ${ }^{13}$.

b) Under BN, cronyism has been rampant, and the police force corrupted ${ }^{14}$.

c) BN has been too tainted by corruption scandals. Anti-corruption agencies have been acted mainly on small fish, leaving the big ones swimming free. Even if there are cases involving big names, it is all just for show, not a true indication of the government's seriousness in combating corruption ${ }^{15}$.

d) Society, as ruled by BN, has been marked by corruption and cronyism ${ }^{16}$.

3) State-endorsed racism

a) $\mathrm{BN}$ endorses racism in favor of the Malays and Bumiputras.

4) MCA and MIC failure; the two main parties aligned with UMNO, the MCA and the MIC, have ignored the plight of the communities they are supposed to represent. The two have mostly been the "lapdogs" of UMNO ${ }^{17}$.

5) BN has simply been too long in power. Change would be good; change of government is normal in other

\footnotetext{
9“Crime fears go viral in Malaysia”, AFP, 10 August 2012.

10“Can Malaysia beat the Middle-Income Trap?” Vikram Nehru, Carnegie Endowment for International Peace, http://carnegieendowment.org/2013/02/22/can-malaysia-beat-middle-income-trap/fj9z.

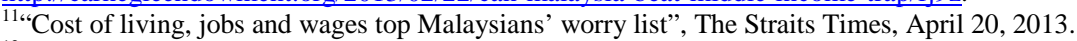

12 "Lowest Chinese and Indian representation in the civil service in the 53-year history of Malaysia-5.8\% Chinese and $4 \%$ Indians as at end of 2009”, Lim Kit Siang blog,

http://blog.limkitsiang.com/2010/04/07/lowest-chinese-and-indian-representation-in-the-civil-service-in-the-53-year-history-of-malaysia-\% E2\%80\%93-5-8-chinese-and-4-indians-as-at-end-of-2009/.

13“Big spender Najib splurge RM58 billion for election, top in region”, Harakahdaily, 23 April 2013.

${ }^{14}$ See "Solar deal fiasco latest proof of BN cronyism and corruption",

http://www.topsecretwriters.com/2012/07/solar-deal-fiasco-latest-proof-of-bn-cronyism-and-corruption/\#more-18499.

${ }^{15} \mathrm{Blog}$ post such as this is typical- "BN's latest tactic: Big fish, small case”,

http://malaysiansmustknowthetruth.blogspot.com/2010/12/bns-latest-tactic-big-fish-small-case.html.

${ }^{16}$ See comments by Enlightenment in "Bring Down Government”, http://chedet.cc/?p=991.

${ }^{17}$ See for example "MIC, MCA are dumber than you imagined".

http://johorpkr.blogspot.com/2013/04/mic-mca-are-dumber-than-you-imagined.html
} 


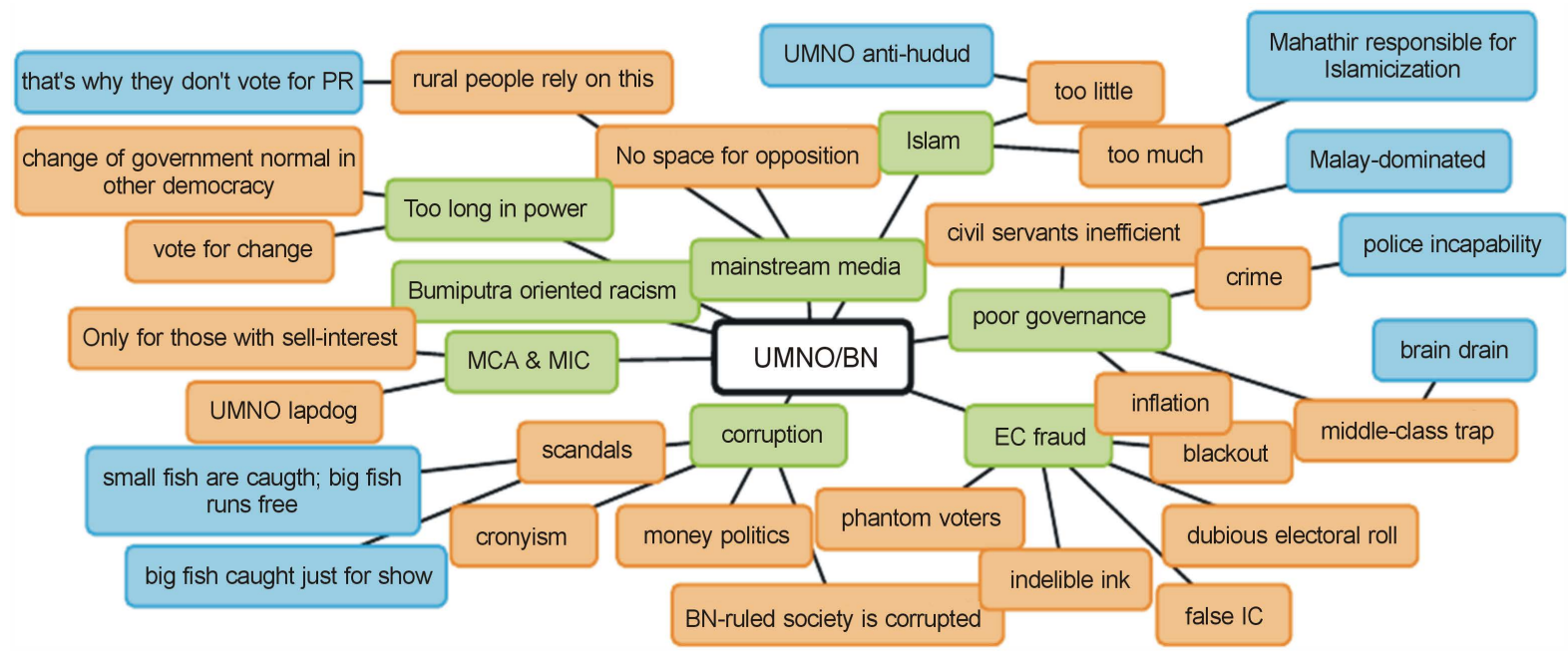

Figure 2. PR worldview.

democracies ${ }^{18}$.

6) Abuse of mainstream media; Mainstream media provides no space for the opposition, and government has abused it to ensure control over rural people, which is why they keep voting for $\mathrm{BN}^{19}$.

7) Islam; for PAS followers, BN has shown too little Islamism²0, while for DAP, BN has shown too much Islamism (see for example Lee, 2010). Note that the dichotomy between the two views, consequential when an Islamist side partners with a secular side, is a known weak spot for the opposition ${ }^{21}$.

8) Election Committee (EC) fraud: Various complaints of cheating have been aired-intentional blackouts allowing for change or addition of ballot boxes, dubious electoral rolls, electorates carrying false IC, failure of supposedly indelible ink, and phantom voters (voters brought in from other district to vote for the ruling party in a particular district) ${ }^{22}$.

In fact, the PR has been sophisticated in reinforcing the worldview in Figure 2 through the manipulation of affect, the political role of which has been well-documented (Glaser \& Salovey 1998; Brader \& Corrigan 2006). PR succeeded in deploying catchphrases that sum the essence of their drive. The message was conjured to stir up visceral association with its cause in fighting an “unjust” and “incompetent” government.

\subsubsection{The BN Worldview}

In the mind of a typical BN supporter, the dominant worldview is as shown in Figure 3 . The primary points in this worldview are that $\mathrm{BN}$ should continue to rule as:

1) The Bumiputra-oriented policies are needed to ensure balanced representations in critical sections of the economy $^{23}$.

2) Historically, UMNO played the main role in fighting for the country’s independence (Adam et al., 2004).

3) UMNO protects the constitution, specifically where the position of the Malay language, Islam and the

\footnotetext{
18“"Why we should change the government”, Free Malaysia Today, February 18, 2013

http://www.freemalaysiatoday.com/category/opinion/2013/02/18/why-we-should-change-the-government/.

19“"PAS: We did lose rural Malay votes but...” Free Malaysia Today, October 15, 2013

http://www.freemalaysiatoday.com/category/nation/2013/10/15/we-did-lose-rural-malay-votes-but/.

${ }^{20}$ See "Nik Aziz says it again: No to cooperation with UMNO", June 20, 2013, Harakahdaily,

http://en.harakahdaily.net/index.php/headline/7428-nik-aziz-says-it-again-no-to-cooperation-with-umno.html.

${ }^{21}$ See "Mahathir's buzz on Islamic State", August 22, 2012

http://anotherbrickinwall.blogspot.com/2012/08/mahathirs-buzz-on-islamic-state.html. See also, “Will DAP remain 'secular first'?” MalaysiaKini, December 17, 2010, http://www.malaysiakini.com/letters/151098.

${ }^{22}$ See for example "Rafizi shows reports on phantom voters, blackouts, demands EC probe”, The Malaysian Insider, May 27, 2013 http://www.themalaysianinsider.com/malaysia/article/rafizi-shows-reports-on-phantom-voters-blackouts-demands-ec-probe/.

23“"Dr M warns NEP removal could lead to revolution”, The Malaysian Insider, August 30, 2010,

http://www.themalaysianinsider.com/malaysia/article/dr-m-warns-nep-removal-could-lead-to-revolution. Also, see: “Agenda ekonomi Bumiputera hak keadilan sosial” (Bumiputera economic agenda as a social justice), September 22, 2013, Juhaidi Yean Abdullah, Berita Harian (http://www.bharian.com.my/bharian/articles/AgendaekonomiBumiputerahakkeadilansosial/Article).
} 


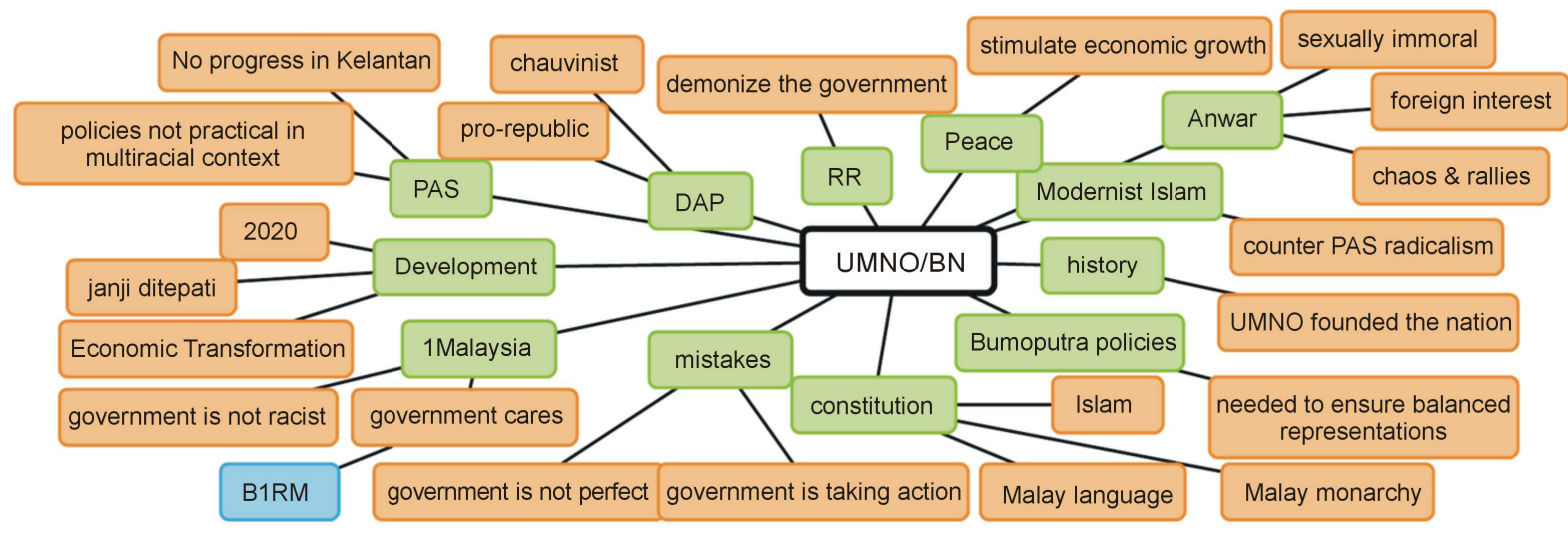

Figure 3. BN worldview.

Malay monarchy are concerned ${ }^{24}$.

4) BN has ensured peace and harmony in the country, and this peace has stimulated continual economic growth $^{25}$.

5) Development in Malaysia, under BN, is directed towards Vision 2020, with the Economic Transformation Programme as the primary driver. Further, the government has made it a point to fulfill whatever promise, social and such, made to the people (Najib's "Janji Ditepati” or "Promises Fulfilled" slogan) ${ }^{26}$.

6) UMNO offers a modernist form of Islam that counters PAS's radicalism ${ }^{27}$.

7) The government acknowledges that there have been mistakes before, in the form of scandals and such committed by BN politicians and ministers. However, the government has been taking actions to correct the mistakes $^{28}$.

8) The BN government through its Malaysia social initiative, has been reaching out to all regardless of race, color and creed. Through nationwide initiatives such as B1RM, the government has shown that it cares for all ${ }^{29}$.

Further, arguments have been put forth as to why PR cannot or should not be allowed to take over the government:

9) Anwar Ibrahim should not be made the prime minister, as he is sexually immoral, has vested foreign interest, and champions his causes through rallies and $\operatorname{chaos}^{30}$.

10) All that PR is good at is in demonizing the government, and it has no concrete alternative to show for all its criticism and condemnation.

11) DAP is chided for its Chinese chauvinism, and its pro-republic stanch (opposed to the monarchy system in Malaysia) ${ }^{31}$.

12) PAS offers policies which are not compatible or practical with the multiracial, multi-religious context in

\footnotetext{
${ }^{24}$ See “Pemerkasaan Ekonomi Bumiputra: Pembangkang Pertikaikan Hak Bangsa Melayu Dalam Perlembagaan?” (“Strengthening Bumiputra Economy; Opposition Questioning Malay Right in Constitution?”), September 16, 2013, MyKMU.net, http://www.mykmu.net/?p=34993 See also, "UMNO perlu pertahan hak dalam kontrak sosial" ("UMNO must defend right in social contract”), November 25, 2008,

http://matahati3.blogspot.com/2008/10/umno-perlu-pertahan-hak-dalam-kontrak.html.

${ }^{25}$ See for example "Voting for BN will ensure peace and stability-Taib” April 27, 2013, The Borneo Post,

http://www.theborneopost.com/2013/04/27/voting-for-bn-will-ensure-peace-and-stability-talib/.

${ }^{26}$ See for example “Opposition doesn’t deserve a second chance, says Najib”, April 30, 2013, The Malaysian Insider,

http://www.themalaysianinsider.com/malaysia/article/opposition-doesnt-deserve-a-second-chance-says-najib.

${ }^{27}$ See for example "In concert protest, PAS youth says not like Taliban”, The Malaysian Insider, October 31, 2011,

http://www.themalaysianinsider.com/malaysia/article/in-concert-protest-pas-youth-says-not-like-taliban. Also see: "PAS at the crossroad", May 6, 2009, The Nutgraph, http://www.thenutgraph.com/pas-at-the-crossroads/.

28“Najib apologises for BN's mistakes in last election”, March 3, 2012, The Star

${ }^{29}$ See information on BR1M at http://www.barisannasional.org.my/en/br1m.

${ }^{30}$ Anwar Ibrahim \& “The Johns Hopkins’ School of Advanced Terror”? March 17, 2013,

http://syedsoutsidethebox.blogspot.com/2013/03/anwar-ibrahim-johns-hopkins-school-of.html.

${ }^{31}$ See for example "A sample of when chauvinist Chinese rules Malaysia!”

http://barkingmagpie.blogspot.com/2013/02/a-sample-of-when-chauvinist-chinese.html.

And "Butcher of Malaya return: DAP chauvinism true colors:

bigdogdotcom.wordpress.com/2009/11/23/butcher-of-malaya-return-dap-chauvinism-true-colours-shown/. Also see: DAP of today like PAP of 1965, April 14, 2013, http://helenang.wordpress.com/2013/04/14/dap-of-today-like-pap-of-1965/.
} 
Malaysia. Further, they have brought no visible progress to Kelantan, the only state in Malaysia where they have been ruling uninterrupted for the past two decades ${ }^{32}$.

In reinforcing its worldview, it is interesting to note the primary affect targeted by BN campaigners has been "fear for the unknown", a powerful political tool (Hatemi, 2013). Malaysia has never been ruled by any party other than BN ever since independence, and the specter of the nation being torn apart once PR is in power proved to be overwhelming for many.

\subsection{The Simulation Framework}

In essence, the simulation framework is influenced by Zaller's (1992) Receive-Accept-Sample (RAS) model; a person keeps multiple views in its head, what kept being determined by her past consideration. At any particular moment, when its opinion is being called for, that which is salient at the moment will be retrieved and effective. We adapt the RAS model to fit in with Malaysian political reality, in particular, as mentioned before, reality as observed on the ground.

Hence, in our simulation, an agent has both positive and negative schema in its mind-“UMNO/BN is bad", denoted $S_{b}$, and "UMNO/BN is good", $S_{g}$. The former is an anti-establishment position, and the latter pro-government. Both are latent in an individual. The scheme which is dominant, that is has more weight, determines whether the agent is a $\mathrm{PR}$ or a $\mathrm{BN}$ supporter.

An emotional filter determines the scheme that is salient at the moment. In fact, in a number of studies (Schemer et al., 2007; Healy et al., 2009), emotion has been shown to be an important determinant of political orientation. While most of the studies were conducted in the context of developed nations, the author noted that it plays a significant role among the Malaysian electorates too, though not quite the same way as with an American electorate for example. A Malaysian with a high stress level, frustrated at the bureaucracy, angry and disappointed, for example with perceived ethnically-driven unfairness or at the ever degrading public transport system, is likely to detach himself from the establishment and side with an opposition party even though he or she might not actually fully endorse the party's position. He or she is likely to start reading only opposition media channels from then on, searching for government's wrong-doing to convince himself or herself that the government is "bad". Hence, the negative schema emerges especially in times of "stress". Still, the positive schema might re-emerge in "better days".

We further note that the 'stress' experienced by an agent may not be real, in the sense that it might not come from actual experiences, but it may in fact be imparted by propagandist media. In fact, the Internet can be used for both information and intentional misinformation. News articles, especially in the Internet, can be articulated to invoke certain emotion and circulated with little consideration for truth, with sometimes adverse effects on the emotion of the electorate. Hence, while the Internet certainly makes it easier for the activists involved to pursue their goals (Farrell, 2012; Aday et al., 2010; Conover et al., 2011), through lowering of the cost of certain kind of collective actions, it allows as well for easier manipulation of the masses, and the materials produced in the words of (Drezner \& Farrell, 2008) can have a "knock-on consequence for the media and for politics". And hence the distaste for it by some government figure, not just in Malaysia, but elsewhere as well, and notably the Turkish Prime Minister, Recep Tayyip Erdogan quipped, "There is now a scourge that is called Twitter. The best examples of lies can be found there. To me, social media is the worst menace to society."

We therefore associate with each agent an emotional state, $e$ - the level of emotion that it has for the government. The higher the emotional state, the happier the agent is with the authority. This is further illustrated below in Figure 4. As shown in the figure, we assume for each agent an emotional value between 0 and 1 . A value above 0.5 indicates a pro-BN emotion, while that below an anti-BN (or pro-PR) feeling. A value of exactly 0.5 can of course be construed as a totally neutral feeling.

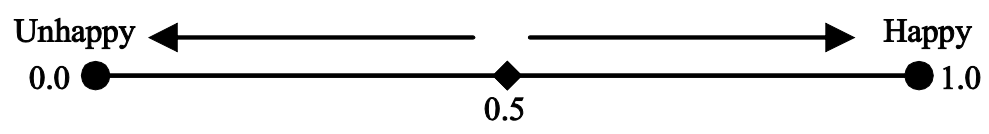

Figure 4. Agent's emotion.

\footnotetext{
${ }^{32}$ See for example: "Muhyiddin gives F to Kelantan PAS”, May 2, 2013, MalaysianDigest.com, http://www.malaysiandigest.com/news/36-local2/332712-muhyiddin-gives-f-to-kelantan-pas.html.
} 
Further, we associate a certain stress level in each of the areas populated by agents. The stress level denotes the environment under which the agent is living, and this stress affects the agent's emotional state. In our experiments, we assume two primary areas-urban and rural. Assuming a Malaysian scenario (might be true anywhere else), urban areas are more populated, and have a higher stress factor, and rural areas are relatively "stress-less". The extent to which environmental stress affects an agent's emotional state depends on its "stubbornness". Stubborn agents will maintain its happiness or unhappiness despite the change in the environmental stress.

Agents are spatially distributed, each with a position $\{x, y\}$. And every agent attempts to influence other agents. Different agents have different level of influence, ifl, measured by a certain radius of influence. Influential agents, to be understood as politicians or individuals with high political interest and engagement, have a higher radius of influence compared to others (the general public). In the actual Malaysian context, they would attempt to assert influence through various medium (Weiss, 2013)—flags, posters, banners, billboards, political rally, walkabouts in markets, neighborhoods, etc., religious services, dinners, and so on. Further, we note the role of the Internet in allowing global communication-broadcasting to the entire population rather than just within a localized target; hence, in the simulation, at each interaction cycle, if an agent, with a probability bcast ${ }_{i}$, uses the media, its influence is set to be arbitrarily large.

When an agent, the propagator, attempts to influence another agent, whether locally or globally (through Internet broadcast), the chances of engagement depends on the similarity of emotional status between the two. An agent happy with the government is likely to engage with another of similar emotion, and similarly with an agent unhappy with the government. Consequently, a stressful agent is not likely to respond to a "positive" influence-BN-oriented agent or view BN material, and likewise an agent already happy in "the way things work" is not likely to make itself interact with "negative" material—PR-oriented agent or believe in PR material. Hence, emotion is assumed to affect attention, a relation documented in a number of works (for example Vuilleumier et al., 2003; Blanchette \& Richards, 2009).

We further associate the notion of mobility with agents. Most agents are static; that is, they will stick to their spatial location, a situation akin to actual society where individuals have work and family to attend to and politics are not central in their life. But some agents are politically-centered individuals or "opinion leaders" (Lazarsfeld et al., 1944), and they will move from one place to another in a direction $\left\{d^{x}, d^{y}\right\}$, wherever they see a chance to spread their influence. Preferential mobility together with selective openness to political discourse, facilitated as noted by (Sunstein, 2002) by the Internet, lead people to become more "inward looking and extreme".

The schema that the propagator engages the receiver on, either $S^{b}$ or $S^{g}$, depends on the emotional states of the two. If both have the same emotional orientation, they will interact using the schema that matches its emotion. For example, if both have PR-oriented emotion, then the schema chosen will be $S_{b}$. If they have different emotional orientation, then the active schema will be the one that matches the schema of the agent with the stronger emotion. If the emotional strengths are equal, the schema chosen will be randomly decided upon with equal probability.

With the schema decided upon, the issue, $\left\{n_{k}, n_{l}\right\}$, within the chosen schema, is then randomly chosen, and the outcome of the interaction probabilistically depends on the communication skill, commsk, of each. If the receiver loses, it will be drawn closer to the opinion of the propagator. The actual amount of increase or decrease of conviction of the receiver on a particular issue depends on its emotional state. Specifically, if the interaction is over $S^{b}$, the receiver will be more inclined to reduce $w^{k l}$ if it is in a good emotional state, and to increase the value otherwise. On the other hand, if the interaction is over $S^{g}$, the receiver will be more inclined to reduce $w^{k l}$ if it is in a bad emotional state, and to increase the value if otherwise.

It should be noted that due to the way we compute the overall weight in a map, as the average over all the weights in the map, the smaller the map, the greater would be the effect of any adjustment of weight. A simple example is as follows: Compare a map, $S_{0}$, with just a single weight, that is with just 2 nodes, to a map, $S_{1}$, with a hundred weights. A change of $\Delta w$ in the single weight in $S_{0}$ would affect its overall weight more than the same change on a single weight in $S_{1}$. Hence, the more complex a map, which means the more complex the predisposition, the slower will be the impact of any change of weight on it, a property in line with Zaller's resistance axiom (1992): People tend to resist, to some extent, arguments that are inconsistent with their political predispositions.

Finally, it is important to note that in our simulation, we assume that any agent, even the staunchest supporter 
or party strongman, can be converted to the opposing side. While studies such as that done by Norris et al. (1999) asserted that due to selective exposure and attention (or confirmation bias), at best, campaign can only reinforce, rather than change partisanship, to "reduce defections from the ranks", the goal of many campaigns in Malaysia has been exactly that - to increase defections from the ranks. In fact, defections can involve even the most hardcore supporters ${ }^{33}$; individuals who used to be top party officials, or even top government leaders, have been known to defect to opposing parties. Hence, any agent, even the mobile ones, can be converted to the opposing side.

In all, an agent, $a_{i}$, has the following key attributes:

- schemas: $S_{b}$ (negative) and $S_{g}$ (positive)

- emotional states, $e_{i}$

- communication skill, commsk

- stubbornness, $s t u b_{i}$

- radius of influence, ifl

- Internet broadcast probability, bcast $_{i}$

- direction, $d^{2} r_{i}$

- position, $\left\{x_{i}, y_{i}\right\}$

At each time step, our agent simulation then works as shown in the following algorithm:

For each time $t$ :

For each agent, $a_{i}$

Set direction dir $_{i}$ to zero vector

Based on its media broadcast probability, bcast ${ }_{i}$, determine randomly if $a_{i}$ is to broadcast.

if $a_{i}$ is to broadcast, temporarily set its if $l_{i}$ to infinity.

For every other agent, $a_{j}$

Compute the probability, $p_{d}\left(a_{i}, a_{j}\right)$, of $a_{i}$ engaging $a_{j}$ based on their distance apart:

$$
p_{d}\left(a_{i}, a_{j}\right)=1-\operatorname{dist}\left(a_{i}, a_{j}\right) / \text { ifl }_{i}
$$

Compute the probability, $p_{e}\left(a_{i}, a_{j}\right)$, of $a_{i}$ engaging $a_{j}$, based on the emotional similarity:

$$
p_{e}\left(a_{i}, a_{j}\right)=1-\left|e_{i}-e_{j}\right|
$$

Based on $p_{d}$ and $p_{e}$, determine randomly if there is interaction between $a_{i}$ and $a_{j}$.

If there is no interaction, continue to the next agent, $a_{j+1}$

Based on emotional status, determine the schema, $S$, (either $S^{b}$ or $S^{g,}$ ) that the agents will interact on.

If both agents with similar emotion, accumulate to dir $r_{i}$ the direction from $a_{i}$ to $a_{j}$

Randomly decides on an issue $\left\{n_{k}, n_{l}\right\}$ within $S$ to be discussed.

Compute the difference in opinion between $a_{i}$ and $a_{j}$ on the issue: $d_{j}=w_{i}^{k, l}-w_{j}^{k, l}$

Determine the probabilityi $p_{\text {win, } i}$, of $a_{i}$ successfully influencing $a_{j}$ :

$$
p_{\text {win }, i}=\operatorname{comm}_{i} /\left(\operatorname{comm}_{i}+\operatorname{comm}_{j}\right)
$$

Determine (in a similar way) the probability, $p_{\text {win }, j}$, of $a_{j}$ successfully countering $a_{i}$.

Based on $p_{w i n, i}$ and $p_{w i n, j}$, randomly compute a boolean flag win ${ }_{i}:$ win $_{i}$ is true if $a_{i}$ managed to influence $a_{j}$, and $a_{j}$ did not succeed in countering back the influence.

If win $_{i}$ is true:

get random val, rval

compute unhappiness $_{j}=1-$ emo $_{j}$

if $S$ is equal to $S_{b}$

$$
\begin{aligned}
& \text { if } d_{j}<0 \\
& \text { else } \\
& \text { compute incr }=1-\text { unhappiness }_{j} \\
& \text { compute incr }=1-\text { happiness }_{j}
\end{aligned}
$$

\footnotetext{
${ }^{33}$ For an example of high-profile PR-to-BN defection, see “'Repented’ Mat Taib now tells Malays to back DAP”, April 25, 2013, The Malaysian Insider, http://www.themalaysianinsider.com/malaysia/article/repented-mat-taib-now-tells-malays-to-back-dap. For an example that goes the other way round, see “Two former PKR leaders to join UMNO”, May 30, 2013, The Star.
} 


$$
\begin{aligned}
& \text { else } \\
& \text { if } d_{j}<0 \\
& \text { compute incr }=1-\text { happiness }_{j} \\
& \text { else } \\
& \text { compute incr }=1-\text { unhappiness } \\
& \text { compute } w^{k l}{ }_{j}=w^{k l}{ }_{j}+\text { rval } * \text { incr } * d_{j}
\end{aligned}
$$

After each time step, we perform the following updates:

- each agent, $a_{i}$, is moved according to its accumulated motion direction, $d^{2} r_{i}$

- the emotion, $e_{i}$, for $a_{i}$ is perturbed based on the current environment stress factor, stress. The adjustment, incr, is randomly proportionate to the inverse of the stubbornness, $s t u b_{i}$, of the agent, as shown below:

$$
\begin{aligned}
& \text { emo }=1-\text { stress } \\
& \text { emoDiff }=\text { emo }-e_{i} \\
& \text { incr }=\text { random fraction } *\left(1-\text { stub } b_{i}\right) \\
& e_{i}=e_{i}+\text { incr } * \text { emoDiff }
\end{aligned}
$$

A brief note on the implementation: We implemented the algorithm above in the C language. While the majority of social simulation work appears to rely on higher-level tools such NetLogo (Gilbert \& Troitzch, 2005), we chose a lower-level language in order to take full advantage of the multicore platform where we run the experiments. Running in parallel on the multicore platform, we were able to execute thousands of runs of the simulation in a reasonable amount of time. The experiments are described in the next section.

\section{Experimental Results and Discussion}

The central political plot in the period of time surrounding GE13, as described early in the paper, pit an embattled BN against a PR side manned by more competent politicians. Hence, we ran simulation experiments to explore various scenarios within that context. The key agents manipulated in the experiments were the mobile, politically-centered agents- $n t B N$ and proBN. The stubbornness values, and the initial values for emotion and positive opinions (which are proportional to the edge weights in the positive schema, and inversely to that in the negative schema), shown in Table 1, are chosen to differentiate between the two sides. The population sizes for both groups were variable, ranging in the experiment from 100 to 500. In conforming to the desired context, $n t B N$ agents in general were assumed to have better communication skills compared to proBN; the average communication skills for proBN ranged with a value no more than 60 (out of 100), while that for $n t B N$ at a value always higher than that for $\operatorname{proBN}$.

\begin{tabular}{|c|c|c|c|c|c|c|}
\hline & popsize & mobility & emo & positive & commsk & stub \\
\hline ntBN & $100-500$ & TRUE & 0.2 & 0.2 & $>$ proBN & 0.8 \\
\hline proBN & $100-500$ & TRUE & 0.7 & 0.7 & $<=0.6$ & 0.5 \\
\hline оррТуре & $40 \%$ of other & FALSE & 0.2 & * & 0.2 & 0.7 \\
\hline proType & $60 \%$ of other & FALSE & 0.7 & * & 0.2 & 0.5 \\
\hline
\end{tabular}

The general population, regardless of their political inclination, PR-(oppType) or BN-inclined (proType), had relatively low communication skill. The positive opinions of both oppType and proType were assumed to be completely random, with a uniform distribution in the range between 0 and 1 . As can be seen in the table, there were more proType compared to oppType in the general population, with an approximate ratio of 60 to $40^{34}$. The differences between proType and bnType were namely where stubbornness and emotion were concerned, factors that we might loosely here attribute to political genes (Hatemi, 2012). In fact, aside from differences due to background (Hing \& Ong, 1987: p. 137 for example), BN-type and PR-type individuals, as with liberals and conservatives in American politics (Amodio et al., 2007), can sometimes be recognized based on differences in outlook or thinking style ${ }^{35}$, with the opposition-type individuals often perceived as being more likely to be more

\footnotetext{
${ }^{34}$ This figure more or less reflects the percentage of the general population who was agreeable with the direction of the country towards the end of 2012, according to the survey report "National Public Opinion Survey October 2012; Top Issues of Concern”, Merdeka Center.

${ }^{35}$ Kassim Ahmad commented on Shanon Ahmad as having "PAS-type of thinking” in "Writer of swear book is a life member of PAS", New Straits Times, April 22, 1999. Anes Zubady commented on Shen Yee Aun being "obviously MCA" and Kee being "perceptibly a DAPster" in "Kee Thuan Chye and Shen Yee Aun”, March 15, 2013,

http://www.malaysia-today.net/mtcolumns/letterssurat/55126-kee-thuan-chye-and-shen-yee-aun.
} 
motivated (Weiss, 2013) and entrenched in their position ${ }^{36}$ (hence the higher stubbornness value). In spite of the predisposition, it is important to note that, subject to the right setting, each individual may incline herself to either side, in the course of a political campaign.

For all continuous random attribute values used in the experiment, the value for each agent was chosen randomly using a Gaussian distribution that centered on the stated values and with a standard deviation $10 \%$ of the values. The total population was fixed at 10,000 and the number of time-step was limited to 50, indicating the time constraint under which either camp had to win over the other side.

The size and population distribution for urban and rural areas were as shown in Table 2. As indicated in the table, more of the population was within the smaller urban area, creating an area with a population density much higher than that for the rural area. The figures in the table more or less reflected the actual figures for Malaysia $^{37}$.

We performed 6 sets of experiments, each set comprising of 1000 runs. The factors being manipulated were indicated in Table 3; ifl corresponding to the influence level of the agents, bcast its broadcasting probability and governance corresponding to lower stress level in urban (citystress) and village area (vlgstress). In experiment 1 , we made it be such that $n t B N$ always had higher infl and bcast, and BN governance was poor (citystress being always more than 0.5). In experiment 2a, we made it be such that proBN always have higher ifl compared to that for $n t B N$. In experiment $2 \mathrm{~b}$, we increased BN's advantage by making proBN's bcast average being always higher than that for $n t B N$. We repeated the sequence of experiments in experiments $3 \mathrm{a}$, 3b and 4, but with BN governance being always good in these rounds (both citystress and vlgstress less than 0.5). The results, to be elaborated upon in the subsections to follow, are shown in Table 4.

\begin{tabular}{ccc} 
Table 2. Urban \& rural setting. & & \\
\hline & radius & percent popsize \\
\hline Urban & 1000 & 0.7 \\
Rural & 7000 & 0.3 \\
\hline
\end{tabular}

Table 3. Experimental setup.

\begin{tabular}{cccc} 
& & BN with more & \\
\cline { 2 - 4 } Exp-1 & ifl & bcast & gov \\
Exp-2a & & & \\
Exp-2b & $\mathrm{x}$ & & \\
Exp-3a & $\mathrm{x}$ & $\mathrm{x}$ & $\mathrm{x}$ \\
Exp-3b & & & $\mathrm{x}$ \\
Exp-4 & $\mathrm{x}$ & $\mathrm{x}$ & $\mathrm{x}$ \\
\hline
\end{tabular}

Table 4. Experimental results.

\begin{tabular}{ccccc}
\hline & PR-vote & BN-vote & PR & BN \\
\hline Exp-1 & 9552 & 448 & 945 & 55 \\
Exp-2a & 9416 & 584 & 928 & 72 \\
Exp-2b & 6323 & 3677 & 477 & 523 \\
Exp-3a & 8623 & 1377 & 939 & 61 \\
Exp-3b & 8381 & 1619 & 917 & 83 \\
Exp-4 & 4302 & 5698 & 401 & 599 \\
\hline
\end{tabular}

\footnotetext{
${ }^{36}$ PAS supporters are seen as being more difficult to win over, in "PAS hardcore supporters urged to wise up", April 26, 2013, Bernama. Also, PR rallies tend to attract bigger, more motivated crowd, compared to BN rallies, as noted in "BN Merdeka Rally at Bukit Jalil versus PR People’s Uprising Rally”, http://weehingthong.wordpress.com/2012/09/02/100000-for-bns-merdeka-day-rally/.

${ }^{37}$ Figures in http://www.geohive.com/earth/pop urban.aspx.
} 


\section{Experiment Set 1: Resourceful ntBN vs. Less Resourceful proBN}

The scenario was that of highly skilled and stubborn PR engaged agents, $n t B N$, up against less resourceful (lower influence range and broadcasting probability) BN agents, $p r o B N$, in a context where BN governed poorly. As shown in Table 1 (Exp-1), PR won emphatically. Two representative cases are shown in Table 5; though PR won 945 out of 1000 experimental runs, we chose one case where PR lost and one where it won.

While it may appear from the table that the number of agents $(n t B N$ or proBN), popsize, played a significant role in determining the outcome, the value was actually randomly generated, and $n t B N$ popsize was greater than proBN popsize in 499 out of the 1000 runs. Figure 5 shows for run 1 the number of conversion to PR made by each of the first 1000 agents during the first simulation iteration. A negative value indicates a conversion to the other side, i.e. to BN. Figure 6 shows the PR voters population dynamic during the first iteration. As can be seen in the figures, the key politically-active agents—ntBN and proBN—forming the first few hundred agents (along the horizontal axis), played the major role in determining the dynamics of electoral conversion. Similar graph profiles are noted for the different runs in different experimental cases, and these will not be reproduced.

In reality, the PR routing of BN as depicted in Experimental Set 1 might be reflected in what Najib referred to as the "Chinese tsunami" ${ }^{38}$ in GE13, an en bloc voting by the Chinese against the ruling coalition. MCA being at a low point was seen to have to failed to campaign effectively among the Chinese population at a time when the community was seen to peak in its agitation and frustration, rightly or wrongly, with the government.

Experiment Set 2a: BN improves Local Propaganda Machinery

The situation in this set was similar to that in Experiment Set 1, but with proBN's radius of influence being always greater than that for $n t B N$. This would in reality be achievable for BN through greater investment in campaign (propaganda) resources-more party workers, longer campaigning period, more banners, posters, more door-to-door visit, more gifts, etc. As shown in Table 4 (Exp-2a), while BN managed to increase the number of times it wins - average of 584 votes per run up from 448 in the previous case, in general, it was still routed by PR. In spite of the greater ifl, the less charismatic (lesser commsk) proBN in the absence of good BN governance, managed to gain only a little more ground for BN.

Two representative cases are shown in Table 6. Note that in run 1, though BN won, it won thinly compared to PR in run 2. Further, note that PR won big in run 2 even though rural stress (vlgstress) was only 33.

\section{Experiment Set 2b: BN improves Local and Global Propaganda Machinery}

The situation was similar to that in Experiment Set 2a, but with proBN's bcast average being always no less than that for $n t B N$. In other words, BN through certain media practice, fair or unfair (not unusual in a semi-democracy like Malaysia—see Schedler, 2006; Heryanto \& Mandal, 2003), dominated and got to channel its propaganda further compared to PR, especially in the Internet.

The effect was dramatic for BN, winning 523 out of 1000 runs, despite still losing the "popular" vote, scoring 3677 against PR's 6323 votes. Two representative cases are shown in Table 7. For run 1, note that even though proBN's bcast value was high, BN won only narrowly compared to PR for run 2. The margin with which BN

Table 5. Representative cases for experiment 1.

\begin{tabular}{|c|c|c|c|c|c|c|c|c|c|c|c|c|}
\hline \multirow{2}{*}{ Run } & \multirow{2}{*}{ citystress } & \multirow{2}{*}{ vlgstress } & \multicolumn{4}{|c|}{ ntBN } & \multicolumn{4}{|c|}{ proBN } & \multirow{2}{*}{ PR } & \multirow{2}{*}{$\mathbf{B N}$} \\
\hline & & & popsize & infl & Commsk & bcast & popsize & infl & commsk & bcast & & \\
\hline 1 & 93 & 79 & 168 & 368 & 52 & 37 & 414 & 286 & 47 & 21 & 3994 & 6006 \\
\hline 2 & 83 & 91 & 424 & 382 & 38 & 31 & 260 & 238 & 13 & 24 & 10000 & 0 \\
\hline
\end{tabular}

Table 6. Representative cases for experiment 2a.

\begin{tabular}{|c|c|c|c|c|c|c|c|c|c|c|c|c|}
\hline \multirow{2}{*}{ run } & \multirow{2}{*}{ citystress } & \multirow{2}{*}{ vlgstress } & \multicolumn{4}{|c|}{ ntBN } & \multicolumn{4}{|c|}{ proBN } & \multirow{2}{*}{ PR } & \multirow{2}{*}{$\mathbf{B N}$} \\
\hline & & & popsize & infl & commsk & bcast & popsize & infl & commsk & bcast & & \\
\hline 1 & 58 & 75 & 431 & 282 & 59 & 22 & 403 & 367 & 57 & 13 & 4141 & 5859 \\
\hline 2 & 55 & 33 & 313 & 406 & 68 & 42 & 345 & 495 & 52 & 15 & 9945 & 55 \\
\hline
\end{tabular}

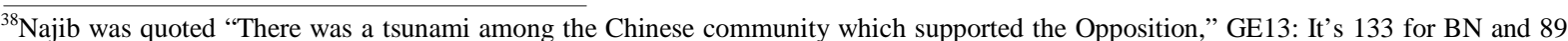
for Opposition, May 6, 2013, The Star. While opposition leaders especially have the claim, there have been substantial arguments that point at the fact—see, for example Calvin Sankaran's Mathematical proof of Chinese Tsunami, July 31, 2013, Free Malaysia Today.
} 
Table 7. Representative cases for experiment $2 \mathrm{~b}$.

\begin{tabular}{|c|c|c|c|c|c|c|c|c|c|c|c|c|}
\hline \multirow{2}{*}{ run } & \multirow{2}{*}{ citystress } & \multirow{2}{*}{ vlgstress } & \multicolumn{4}{|c|}{ ntBN } & \multicolumn{4}{|c|}{ proBN } & \multirow{2}{*}{ PR } & \multirow{2}{*}{ BN } \\
\hline & & & popsize & infl & commsk & bcast & popsize & infl & commsk & bcast & & \\
\hline 1 & 73 & 93 & 489 & 45 & 66 & 9 & 401 & 62 & 27 & 40 & 4446 & 5554 \\
\hline 2 & 79 & 79 & 146 & 43 & 77 & 7 & 217 & 243 & 47 & 7 & 7073 & 2927 \\
\hline
\end{tabular}

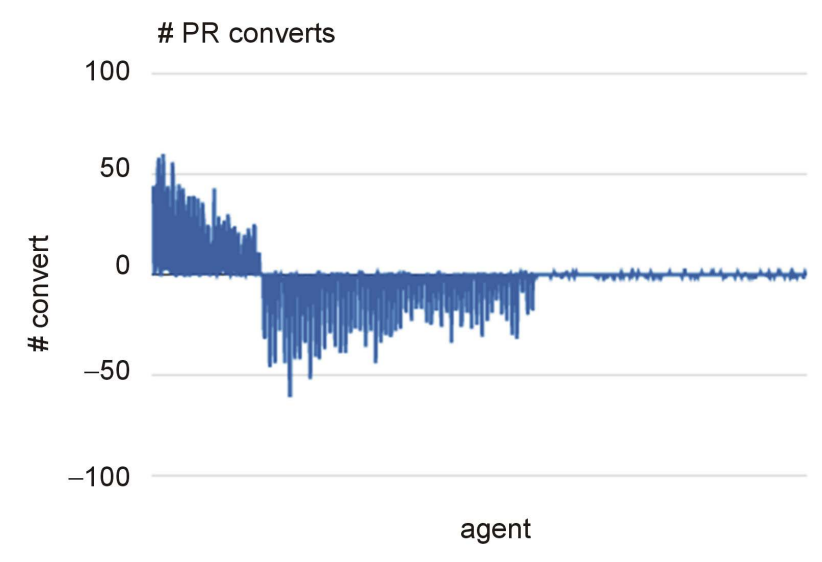

\section{Figure 5. PR conversion.}

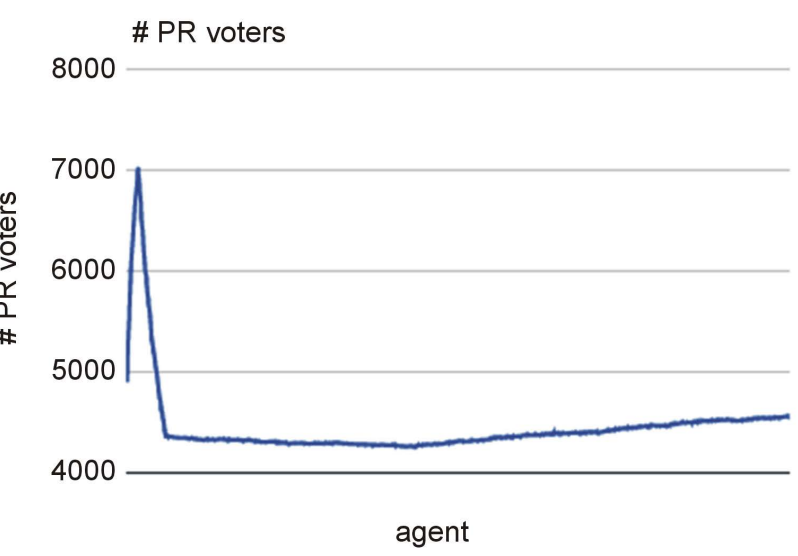

Figure 6. PR population dynamic during first iteration.

was able to improve its win in this experimental set confirms the significance of the Internet in determining electoral swing, as per the discussion in Section 1.

\section{Experiment Set 3a: Repeat Experiment 1 but With BN Governing Better}

In this set, we considered a situation similar to that in Experiment Set 1, but with urban stress factor (citystress) and rural stress factor (vlgstress) both lower than 0.5 (or 50 in the table). This corresponds to the situation where the BN government manages to govern the country well enough to ensure low stress level in both the rural and the urban areas.

While we would expect good governance to translate into votes for BN, simulation results indicate otherwise. As shown in Table 4, BN won only 61 out of 1000 runs and had an average of only 1377 votes, an improvement though over its score in Experiment Set 1, the result shows is that though good governance may help BN, it will not do for the party if its proBN agents are inferior to $n t B N$. Two representative cases are shown in Table 8. Note that in run 2, BN still lost despite having larger popsize and with low citystress and vlgstress.

An actual situation that paralleled the result here (at least contextually) might be the Worker Party victory in Singapore's Punggol East by-election in January 2013. In spite of the ruling party highly regarded governance, it failed to outdo the superiority of the opposition's skilled election machinery. 


\section{Experiment Set 3b: Repeat Experiment 2a but With Better Governance}

In Experimental Set 3b, in a way similar to Experiment Set 3a, we repeated Experiment Set 2a but with BN showing better governance. A slight improvement was made over its result in Experimental Set 2a; BN registering 1619 average votes and winning 83 runs. Two representative cases are shown in Table 9. In run 1, PR edged past BN in spite of its smaller population size. In run 2, a strong BN size with an almost equal bcast measure overran PR.

Experiment Set 4: Repeat Experiment $2 b$ but with Better Governance

Finally, we ran experiments where BN had both better campaign and media machinery, and recorded better governance. In this experimental set, proBN always had ifl and bcast than that for $n t B N$, and the stress levels in both the urban and the rural areas were always less than 50 (out of 100).

The result shows a stunning reversal of fortunes for BN; it won an average of 5698 average votes against PR's 4302, winning 599 runs and losing 401. Two representative cases are shown in Table 10. Note that in run 1, the vlgstress (rural stress) was very low (3 out of 100); but PR won. In run 2, a bigger proBN population helped turned the tide against PR; it is unclear though if population size was the key determinant.

\section{Insight from the Computer Experiments}

As noted in (Sodaro, 2004; p. 71), "the purpose of a model is not to represent reality perfectly but to enable us to understand reality by allowing us to compare it against some standard or pattern". In fact, though a simulation that is only loosely based on actual parameters cannot be expected to mirror the reality exactly, from the results, we can draw the following conjecture:

A ruling political party (or coalition) with agents less skilled in communication can maintain its position provided:

1) It provides good living condition or good governance

2) Its agents make good use of the media (or media policy), especially the Internet, to reach out to the general public further than the opposing parties.

To conclusively prove the conjecture, field work and empirical analysis would certainly be required, and this is beyond the scope of the paper. However, there are evidences hinting at its truth. BN had its biggest electoral victory since 1978 in the 2004, $11^{\text {th }}$ General Election, a year marked by former prime minister, Abdullah Badawi, as "a transitional period, a time of high hopes"39 , and also the year when Malaysian Internet usage was only 42.3 percent (compared to 65.8 percent in 2012). Considering the Internet to be the enabler for the opposition in

Table 8. Representative cases for experiment 3a.

\begin{tabular}{|c|c|c|c|c|c|c|c|c|c|c|c|c|}
\hline \multirow{2}{*}{ run } & \multirow{2}{*}{ citystress } & \multirow{2}{*}{ vlgstress } & \multicolumn{4}{|c|}{$n t B N$} & \multicolumn{4}{|c|}{ proBN } & \multirow{2}{*}{ PR } & \multirow{2}{*}{$\mathbf{B N}$} \\
\hline & & & popsize & infl & commsk & bcast & Popsize & infl & commsk & Bcast & & \\
\hline 1 & 41 & 24 & 250 & 132 & 33 & 10 & 444 & 47 & 27 & 9 & 3556 & 6444 \\
\hline 2 & 29 & 37 & 146 & 243 & 77 & 7 & 217 & 43 & 47 & 7 & 5328 & 4672 \\
\hline
\end{tabular}

Table 9. Representative cases for experiment 3b.

\begin{tabular}{|c|c|c|c|c|c|c|c|c|c|c|c|c|}
\hline \multirow{2}{*}{ run } & \multirow{2}{*}{ citystress } & \multirow{2}{*}{ vlgstress } & \multicolumn{4}{|c|}{ ntBN } & \multicolumn{4}{|c|}{ proBN } & \multirow{2}{*}{ PR } & \multirow{2}{*}{ BN } \\
\hline & & & popsize & infl & commsk & bcast & popsize & infl & commsk & bcast & & \\
\hline 1 & 20 & 24 & 148 & 300 & 85 & 32 & 339 & 333 & 55 & 22 & 5216 & 4784 \\
\hline 2 & 47 & 43 & 301 & 249 & 62 & 24 & 358 & 396 & 42 & 23 & 3657 & 6343 \\
\hline
\end{tabular}

Table 10. Representative cases for experiment 4.

\begin{tabular}{|c|c|c|c|c|c|c|c|c|c|c|c|c|}
\hline \multirow{2}{*}{ run } & \multirow{2}{*}{ citystress } & \multirow{2}{*}{ vlgstress } & \multicolumn{4}{|c|}{$n t B N$} & \multicolumn{4}{|c|}{ proBN } & \multirow{2}{*}{ PR } & \multirow{2}{*}{ BN } \\
\hline & & & popsize & Infl & commsk & bcast & Popsize & infl & commsk & bcast & & \\
\hline 1 & 41 & 3 & 244 & 250 & 46 & 24 & 142 & 294 & 21 & 44 & 8523 & 1477 \\
\hline 2 & 29 & 15 & 140 & 246 & 88 & 23 & 314 & 355 & 41 & 43 & 3903 & 6097 \\
\hline
\end{tabular}

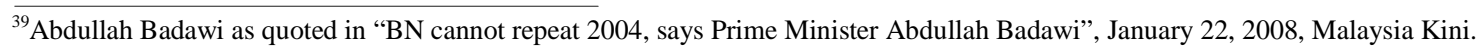


Malaysia, it is evident that the "feel good" factor together with the opposition's lack of media access then allowed a convincing win for BN. A further example is to the south of the country, in Singapore, where Shiang $\mathrm{Nee}^{40}$ noted that the ruling PAP seems to have recognized that for it to maintain its support base, it needs taking "a harder line against dissent and resisting pressure for political reforms, but giving out more economic benefits for voters that count the most—-the middle class". "Harder line" here inevitably implies censuring of Internet media.

\section{Limitation and Future Work}

One limitation of the work is that we assume that everyone has access to the Internet. While the importance of the Internet has been highlighted by many in the literature and in the political circles, and confirmed in the simulation experiments, in actuality, not everyone in Malaysia has easy access to the medium. Those in the deep rural areas are not likely to tune to it, even if they do have the opportunities to do so, either out of cost concern or out of a simple preference for traditional, low-technology lifestyle. Hence, future work should consider low-technology group of agents.

Also, we could have conducted a statistically more rigorous data analysis of the experimental results. For example, it would be interesting to study the statistical correlation between the various parameters manipulated within the experiments. We feel however that such analysis would be meaningful only when tied to an actual field study.

Further, we note that the agent-based simulation as presented here can be extended to capture more of the political complexity in Malaysia. The role of political networking for example can be better captured in the simulation, that being a significant factor especially in the rural electorate (Weiss, 2013).

Finally, though the use of worldview maps makes explicit the structure of the opinion of individual agents, to make the simulation more realistic, there should be an individual bias in the way in which an agent chooses and communicates on a topic when it is trying to influence another agent. It would then be interesting to see how the semantic of the opinion can possibly affect the simulation results.

\section{Conclusion}

We have presented an agent-based simulation model that describes the propagation of political perception or belief in Malaysia. Worldview map is used as the token that represents political belief. Computational experiments were made using parameters inspired by the situation "on the ground". The results obtained do point to the plausibility of the model, at least in the qualitative sense. In essence, the work shows that it is possible to capture the dynamics of Malaysian politics in the form of social simulations.

The results suggest a complex interrelation between the various parameters in the political setup, and it highlights the importance of the Internet in determining electoral swing. And most importantly, it suggests the importance, for the ruling coalition, of both a strong political propaganda machinery and a strong governance in winning and maintaining the hearts and minds of the electorate.

\section{References}

Adam, R., Samuri, A. H., \& Fadzil, M. (2004). Sejarah Tingkatan 3 (pp. 60-65, 75). Malaysia: Dewan Bahasa dan Pustaka.

Aday, S., Farrel, H., Lynch, M., Sides, J., Kelly, J., \& Zuckerman, E. (2010). Blogs and Bullets; New Media in Contentious Politics. Peaceworks Report. Washington DC: United States Institute of Peace.

Aisen, A., \& Veiga, F. J. (2011). How Does Political Instability Affect Economic Growth? IMF Working Paper 2011. Washington DC: International Monetary Fund.

Amodio, D. M., Jost, J. T., Master, S. L., \& Yee, C. M. (2007). Neurocognitive Correlates of Liberalism and Conservatism. Nature Neuroscience, 10, 1246-1247. http://dx.doi.org/10.1038/nn1979

Blanchette, I., \& Richards, A. (2009). The Influence of Affect on Higher Level Cognition: A Review of Research on Interpretation, Judgment, Decision Making and Reasoning. Cognition \& Emotion, 24, 561-595.

Brader, T., \& Corrigan, B. (2006). How the Emotional Tenor of Ad Campaign Affects Political Participation. Philadelphia: Annual Meeting of the American Political Science Association.

Conover, M. D., Ratkiewicz, J., Francisco, M., Goncalves, B., Flammini, A., \& Menczer, F. (2011). Political Polarization on

\footnotetext{
${ }^{40}$ See Chiang Nee’s column, “PAP plan to retain support”, August 31, 2013, The Star.
} 
twitter. 5th International AAAI Conference on Weblogs and Social Media, Barcelona.

Deffuant, G., Amblard, F., Weisbuch, G., \& Faure, T. (2002). How Can Extremism Prevail? A Study Based on the Relative Agreement Interaction Model. Journal of Artificial Societies and Social Simulation, 5. http://jasss.soc.surrey.ac.uk/5/4/1.html.bak

Drezner, D. W., \& Farrell, H. (2008). The Power and Politics of Blogs. Public Choice, 134, 15-30.

Farrell, H. (2012). The Consequences of the Internet for Politics. Annual Review Political Science, 15, 35-52. http://dx.doi.org/10.1146/annurev-polisci-030810-110815

Geller, A., Rizi, S. M. M., Latek, M. M., \& Thies, C. (2011). State Capacity and Conflict: Evidence from Afghanistan. 2011 Computational Social Science Society of America Annual Conference, Santa Fe.

Gilbert, N., \& Troitzch, K. G. (2005). Simulation for the Social Scientist (2nd ed.). London: McGraw Hill.

Glaser, J., \& Salovey, P. (1998). Affect in Electoral Politics. Personality and Social Psychology Review, 2, 156-172. http://dx.doi.org/10.1207/s15327957pspr0203_1

Gulden, T. (2012). Modeling Selective Violence in the Guatemalan Civil War. 2012 Computational Social Science Society of America Annual Conference, Santa Fe.

Hatemi, P. K., Medland, S. E., Klemmensen, R., Oskarrson, S., Littvay, L., Dawes, C., Verhulst, B., McDermott, R., Nørgaard, A. S., Klofstad, C., Christensen, K., Johannesson, M., Wright, M. J., Montgomery, G. W., Eaves, L. J., \& Martin, N. G. (2012). Genetic Influences on Political Ideologies: Genome-Wide findings on Three Populations, and a MegaTwin Analysis of 19 Measures of Political Ideologies from Five Western Democracies. Behavior Genetics Association 42nd Annual Meeting Abstracts.

Hatemi, P. K., McDermott, R., Eaves, L. J., Kendler, K. S., \& Neale, M. C. (2013). Fear as a Disposition and an Emotional State: A Genetic and Environmental Approach to Out-Group Political Preferences. American Journal of Political Science, 57, 279-293. http://dx.doi.org/10.1111/ajps.12016

Healy, A. J., Malhotra, N., \& Cecilia, H. (2009). Personal Emotions and Political Decision Making: Implications for Voter Competence. Annual Meeting of the American Political Science Association, Toronto.

Heryanto, A., \& Mandal, S. K. (2003). Challenges to Authoritarianism in Indonesia and Malaysia. In A. Heryanto, \& S. K. Mandal (Eds.), Challenging Authoritarianism in Southeast Asia; Comparing Indonesia and Malaysia. Oxford: Routledge.

Hing, L. K., \& Ong, M. (1987). Malaysia. In M. Weiner, \& E. Özbudun (Ed.), Competitive Elections in Developing Countries. Washington DC: American Enterprise Institute for Public Policy Research.

Iniguez, G., Barrio, R. A., Kertesz, J., \& Kaski, K. K. (2011). Modeling Opinion Formation Driven Communities in Social Networks. Computer Physics Communications, Elsevier, 182, 866-1869.

Kottonau, J., \& Wostl, C. P. (2004). Simulating Political Attitudes and Voting Behavior. Journal of Artificial Societies and Social Simulation, 7. http://jasss.soc.surrey.ac.uk/7/4/6.html

Lee, J. C. H. (2010). Islamization and Activism in Malaysia. ISEAS Series on Islam. Malaysia: Strategic Information \& Research Devt Centre (SIRD).

Mare, A. D., \& Latora, V. (2007). Opinion Formation Models Based on Game Theory. International Journal of Modern Physics C, 18, 1377-1395. http://dx.doi.org/10.1142/S012918310701139X

Muis, J. (2010). Simulating Political Stability and Change in the Netherlands (1998-2002): An Agent-Based Model of Party Competition with Media Effects Empirically Tested. Journal of Artificial Societies and Societal Simulation, 13, pp.

Norris, P., Curtice, J., Sanders, D., Scammell, M., \& Semetko, H. A. (1999). On Message: Communicating the Campaign. Thousand Oaks, CA: Sage Publications.

Salleh, H. M. (2010). 1Malaysia-Concept and Values. http://www.kettha.gov.my/sites/default/files/uploads/1Malaysia\%20-\%20Concept\%20and\%20Values.pdf

Schedler, A. (2006). The Logic of Electoral Authoritarianism. In A. Schedler (Eds.), Electoral Authoritarianism (pp. 1-23). Boulder, CO: Lynne Rienner Publisher.

Schemer, C., Wirth, W., \& Matthes, J. (2007). The Emotional Underpinnings of Democracy-The Impact of Positive and Negative Affect in a Political Campaign in Switzerland. Working Paper No. 13, WAPOR 60th Annual Conference on Public Opinion and the Challenges of the 21st Century, Berlin, 19-21 September 2007.

Sieck, W. R. (2010). Cultural Network Analysis: Method and Application. In D. Schmorrow, \& D. Nicholson (Eds.), Advances in Cross-Cultural Decision Making (pp. 260-269). Boca Raton, FL: CRC Press/Taylor \& Francis, Ltd.

Sieck, W. R. (2011). A Cultural Model Approach for Investigating the Cognitive Basis of Terrorism. Journal of Terrorism Research, 2, 3-15.

Silverman, B. G., Bharathy, G., \& Nye, B. (2006). Gaming and Simulating Ethnopolitical Conflicts. Decartes Conference on Mathematical Models in Counterterrorism, Washington DC, 26-28 September 2006, 275-302. 
Sodaro, M. J. (2008). Comparative Politics: A Global Introduction (3rd ed.). New York: McGraw-Hill.

Subramaniam, S. (2011). Assessing Political Dynamics in Contemporary Malaysia: Implications for Democratic Change. ASIANetwork Exchange, 19, 42-52.

Sunstein, C. R. (2002). Republic.com. Princeton, NJ: Princeton University Press.

Vuilleumier, P., Armony, J., \& Dolan, R. (2003). Reciprocal Links between Emotion and Attention. In R. S. J. Frackowiak et al. (Eds.), Human Brain Function (2nd ed., pp. 419-444). San Diego, CA: Academic Press.

Weiss, M. (2013). Electoral Dynamics in Malaysia: Findings from the Grassroots. Selangor, Malaysia: Strategic Information and Research Development Center.

Zaller, J. R. (1992). The Nature and Origins of Mass Opinion. Cambridge: Cambridge University Press. http://dx.doi.org/10.1017/CBO9780511818691 